\title{
THE PROFESSIONAL SITUATION OD DISABLED PEOPLE ON THE BIESZCZADY POVIAT
}

doi: 10.2478/czoto-2021-0025

Date of submission of the article to the Editor: $03 / 12 / 2020$

Date of acceptance of the article by the Editor: 25/03/2021

\author{
Magdalena Tkacz ${ }^{1}$ - orcid id: 0000-0002-0999-1643 \\ ${ }^{1}$ Podkarpackie Centre for Teaching Services, Poland
}

\begin{abstract}
The aim of the article is to present the functionality of unemployed disabled people at the shows of the Bieszczady poviat based on the data presented in individual documents. The article is important for people with disabilities in relation the problems that plague them in carrying out everyday places. For many patients, work is an opportunity to break away from everyday problems and function on the basis of meeting subsequent goals related to professional work.
\end{abstract}

Keywords: the disabled, unemployment, employment, employer, enterprise, employee

\section{INTRODUCTION}

Performing professional duties is one of the basic activities which a person should commit to. It does not make any difference in the case of employees belonging to one of the groups of physical disability who, due to the occurrence of this disability, face additional difficulties in finding a well-paid job. The obstacles that occur in their cases, and which affect their finding a job, focus not only on architectural barriers, but also on the society's approach, including the potential employer, to the issue of employing a disabled person.

Considerations on the employment of disabled people should start with explaining the basic terminology related to this issue. Thus, Mitra claims that a disability is disability a problem of the individual that is directly caused by a disease, an injury, or some other health condition and requires medical care in the form of treatment and rehabilitation. (Mitra, 2006).

On the other hand, the current law on vocational and social rehabilitation recognizes that a disabled person is a person whose disability has been certified, is completely or partially incapable of work, or has been classified to one of the three degrees of disability. (Dz. U. $1997 \mathrm{nr} 123$ poz. 776)

The United Nations Convention on the Rights of Persons with Disabilities recognizes as disabled persons those who have long-term or permanent physical, mental or intellectual limitations, which makes their participation in society much more difficult. (UN Convention on the Rights of Persons with Disabilities).

The Act cited earlier also indicates three applicable degrees of disability: 
- Moderate - these include those with impaired efficiency of the organism, unable to work or can perform it only under the conditions of sheltered work or requiring the help of other people to perform social roles.

- Mild - these include those who have impaired body efficiency, have a significantly reduced ability to work compared to a fully functional person with similar professional qualifications or limitations that can be compensated by appropriate measures.

- Severe - these include those who have impaired body efficiency, are unable to work or can perform it only in sheltered employment conditions or requiring the help of other people for social roles or long-term care and help for independent living. (Dz. U. 1997 nr 123 poz. 776).

Thus, the legislator tries to classify disabled persons into one of the three categories by exhausting the catalog of possibilities. However, it can be noticed that it uses general phrases that do not directly refer to both physical and intellectual disability. Through such a procedure, it is possible to regulate the standards of treating the disabled by individual administrative bodies, and to adjust the measures taken towards them to the actual needs.

From the point of view of ergonomics, in order to employ a disabled person in a given enterprise, it is necessary to adapt the potential place of employment to the requirements and needs of the disabled. It is indicated that the proper adaptation of the workplace should take into account the following factors:

- Ensuring recruitment and selection procedures are accessible to all,

- Adapting the working environment,

- Providing assistive devices,

- Modifying working schedules. (de Guimarães, 2012)

It can be said that the above-mentioned elements can be successfully used not only in relation to disabled people, but also in relation to fully healthy employees. Each of them should be guaranteed conditions for the effective and safe performance of their duties, and negligence in this aspect is a significant burden for the employer - both in terms of financial issues and the image. Hence, it is so important to provide employees with conditions that are tailored to the needs and requirements of the work performed (Saja et al., 2017).

A potential employer, after analyzing the situation related to the employment of a disabled person, needs to consider a few more elements and factors that should be considered in the process of planning such a move. They include, among others:

- A pace of performed tasks adapted to the needs and capabilities of the employee,

- A possibility of introducing a break in the event of an employee being overloaded with duties,

- Conducting training in the field of evacuation from the workplace,

- An indication of the path of professional development in line with the expectations and psychosocial characteristics of the employee,

- Issuing clear and concise messages regarding the work performed,

- Providing feedback on the work performed. (Żołnierczyk-Zreda et al., 2016).

All these elements result in the creation of a workplace for disabled employees in accordance with their preferences, but also adapted to the type of disability, thanks to which theu are able to safely perform their duties. 


\section{EMPLOYMENT OF A DISABLED WORKER}

An approach of an employee, both healthy and disabled, to their professional work is an individual matter. For a disabled employee, an opportunity to work is something more than just duties - it is the opportunity to gain financial independence, allowing for self-satisfaction of the most basic needs. E. Jaglarz distinguished several reasons why work for an employee with a disability was such an important element of everyday functioning:

1. It is a source of income - it allows meeting the most essential life needs and cover at least some of the costs related to the patient's disability.

2. It gives a sense of value and social usefulness - it enables the disabled to feel part of the community and work for it.

3. Work is a form of spending free time - disabled people who often have problems with finding employment may treat work as a form of spending their free time, making their everyday life more fun.

4. Work strengthens the sense of meaning in life - it allows one to define life goals and provides funds for their implementation.

5. It allows the development of a mechanism of functioning and dealing with potentially difficult situations - failures and challenges appearing on the professional ground mean that every employee, not only the disabled one, has to work out a method of dealing with the consequences of such situations.

6. It helps to increase activity - a disabled person, due to their work, must increase the scope of their activity - not only physically but also mentally, which has a generally beneficial effect on their functioning (Jaglarz, 2017).

As can be seen from the above-mentioned list, work is not limited to material factors, but is an important aspect of functioning for a disabled person - it allows them to feel part of society and strive for self-fulfillment, and enables them to achieve a greater degree of integration with colleagues, which is a particularly important function if one takes into account the feelings of loneliness and rejection that people with disabilities often feel.

Employment of a disabled employee requires a number of actions not only in terms of breaking architectural barriers. It is necessary for an enterprise to meet several conditions that will allow safe employment and effective performance of duties by a disabled employee. The National Labor Inspectorate indicates that the employment of a disabled person may be allowed under the following conditions:

- Compliance with the principle of non-discrimination - is associated not only with the broadly understood prohibition of discrimination against an employee, but also with the employer's obligation to adapt the work environment to the requirements that will allow the employee to perform work safely and effectively.

- The working time of a disabled person may not exceed 8 hours a day and 40 hours a week, and in the case of persons with a severe and moderate degree of disability, 7 hours a day and 35 hours a week.

- Prohibition of employing a disabled employee at night - with two exceptions - the rule does not apply to the persons employed to supervise and in the event that the doctor determines that there are no grounds prohibiting work at night, and the examination is carried out at the employee's request and employer's expense.

- An obligation to provide an additional break for a disabled employee of 15 minutes. 
- An obligation to provide additional holiday leave for a disabled employee belonging to the severe or moderate disability category. The leave is not granted to an employee who has the right to rest exceeding 26 working days or to a person who is entitled to additional leave on the basis of separate notes in force.

- Ensuring the right to be released from professional duties while retaining the right to receive remuneration for the time of performing specialist examinations, medical treatments, obtaining orthopedic support or its repair or, once a year, by participating in a rehabilitation camp not exceeding 21 working days (Your social security rights in Poland).

Taking into account all the determinants that must be met by the employer in order to employ a disabled person, it can be concluded that the privileges are mainly aimed at protecting a disabled employee, but do not take into account the elements that the employer must bear in connection with employment. As a result of this situation, coworkers may also have a negative attitude towards the disabled in relation to their rights. All these elements make finding a job for a disabled person a challenge.

The situation of people with disabilities in the labor market has been significantly influenced by the SARS-CoV-2 coronavirus pandemic. Due to the systems commonly introduced by the largest countries in the world aimed at closing the economy, many employees of individual enterprises, including the disabled, found themselves in a difficult situation. Hence, it becomes necessary to develop solutions that will adequately protect the disabled. Therefore, the solutions proposed by the legislator include the following:

- Increasing the base amount for a severely disabled employee from PLN 1.800 to PLN 1.950,

- Increasing the base amount for an employee with moderate disability from PLN 1.125 to PLN 1.200,

- Increasing the base supplement for people with special illnesses for people with severe disabilities from PLN 600 to PLN 1.200,

- Increasing the base benefit for people with special illnesses for people with moderate disability from PLN 600 to PLN 900. (https://www.rp.pl/Niepelnosprawni/303309932Koronawirus-doplaty-dla-pracownikow-niepelnosprawnych.html).

On the other hand, an employer taking on a disabled employee may waive the obligation to pay the prolongation fee when applying for a deferment or spreading payment into installments, and from the obligation to charge an additional fee when applying for a deferment of payment or spread it into installments (Ibid.).

It is also worth mentioning that employing a disabled employee is associated with an obligation to prepare an occupational risk assessment for them, which will have to include the risks associated with disability. Performing such an estimation should take place after a careful study of the nature and position of the job in full cooperation with the disabled and the employer. An indication of situations that may trigger potentially dangerous events must be adjusted to the workplace and its position. In the case of people with disabilities, the risks will include:

- A fall (both from a height and when losing balance),

- Tipping over of a wheelchair,

- The stroller hits the surroundings at the workplace,

- Hand injuries related to operating the truck. 
Employment of a disabled worker has a significant impact on the entire workplace. Therefore it is necessary to ensure that the working environment is properly equipped and that the employer guarantees the highest possible level of safety, not only for the disabled, but also for the entire environment.

\section{A DISABLED WORKER IN THE BIESZCZADY POVIAT}

Adapting not only the working environment, but all public buildings to the needs of disabled people, is a challenge that Poland is not coping well with. Many facilities, including offices, are not adapted to accommodate a disabled employee-to be. It is also directly related to the conditions of employment of disabled people - many opportunities are closed to them due to barriers, mainly architectural ones, which effectively prevent them from taking up employment. The summary of this problem can be shown on the example of the Bieszczady poviat, based on the data compiled in the Strategy for solving social problems in the Bieszczady poviat for the years 2020-2026.

Overall, the unemployment situation in the poviat is presented in a way that differs significantly from the data comparing the entire country in this approach, as presented in the table below.

Table 1

The level of unemployment in the Bieszczady poviat in comparison to nationwide data

\begin{tabular}{|l|l|l|l|}
\hline & \multicolumn{1}{|c|}{$\mathbf{2 0 1 6}$} & \multicolumn{1}{c|}{$\mathbf{2 0 1 7}$} & \multicolumn{1}{c|}{$\mathbf{2 0 1 8}$} \\
\hline Poland & 8.3 & 6.6 & 5.8 \\
\hline Bieszczady poviat & 18.2 & 15.3 & 13.9 \\
\hline
\end{tabular}

Source: Strategy for solving social problems in the Bieszczady poviat for the years 2020-2026

As one can notice on the example of the data cited, the number of unemployed people in the Bieszczady poviat is high, and thus the competition in the labor market is equally high. It should be remembered that every year successive groups of graduates of individual schools join the group of people looking for a job, and thus constitute a very strong competition also for potential disabled employees. In such an approach, the entire period of time during which a person was unemployed works to the disadvantage of a disabled employee, which significantly reduces their knowledge of the market, which is effectively filled by new jobseekers. Therefore, a disabled person is faced with the need to constantly improve themselves and their abilities, which keeps them competitive.

The structure of people with disabilities in the Bieszczady poviat is no longer as drastically high as it was in the case of the overall unemployment level in the poviat.

Table 2

Number of people with disabilities in the Bieszczady poviat

\begin{tabular}{|l|l|l|l|}
\hline $\begin{array}{c}\text { The unemployed by } \\
\text { the degree of } \\
\text { disability }\end{array}$ & $\mathbf{2 0 1 6}$ & $\mathbf{2 0 1 7}$ & $\mathbf{2 0 1 8}$ \\
\hline Severe & 3 & 0 & 0 \\
\hline Moderate & 11 & 13 & 12 \\
\hline Mild & 33 & 21 & 22 \\
\hline
\end{tabular}

Source: Strategy for solving social problems in the Bieszczady poviat for the years 2020-2026 
The data collected indicate that the highest percentage of disabled people in the Bieszczady poviat has a slight degree of disability. Consequently, there are no major obstacles preventing them from finding a job. It can be concluded that the main reason why people with disabilities do not find employment in the Bieszczady poviat is not the problem of architectural obstacles, but the inability to find a job that would meet the expectations and needs of the disabled. The poviat, as an institution, tries to undertake adequate actions aimed at activating disabled people who are unemployed. This is done mainly by benefits granted under PFRON, which in turn are allocated to the following purposes:

- expenditure related to labor market instruments or services for people with disabilities who are unemployed,

- job placement, retraining and training of the disabled unemployed,

- expenses related to the purpose for the needs related to starting a business,

- referral of disabled people who require specialized training and therapeutic rehabilitation to an appropriate facility,

- providing legal and economic consultancy services in the field of business or agricultural activities undertaken by disabled people,

- cooperation with a labor inspector on jobs for disabled people. (Strategy for solving social problems in the Bieszczady poviat for the years 2020-2026)

Therefore, the activities undertaken in the field of employing a disabled person are broad and focused on matching the appropriate job offer to the unemployed. However, taking into account the conditions in the poviat and the highly limited employment opportunities, it cannot be concluded that these measures were sufficient. As it is commonly known, the Bieszczady poviat is one of the areas in Poland that cannot efficiently and quickly offer employment opportunities to the disabled. This is, among others, due to the difficult terrain - potential employment may require moving, which would not necessarily be a desirable and safe phenomenon for a disabled person. Another aspect is the lack of large work centers in the poviat that could offer safe employment. Therefore, it would be desirable to make the poviat area more attractive in terms of investment, which could significantly increase employment opportunities, not only for disabled workers. The Strategy quoted earlier indicates that the geographical configuration is an important factor that hinders finding a job by disabled people - many sick people live in the countryside, and the agricultural sector becomes the main area of employment, which cannot always afford employment for the disabled. Despite the fact that the largest group of disabled people in the poviat are people with mild disabilities who could theoretically find employment in the agricultural area, the risk of such employment is high and not very safe for an employee. Also, work in the agricultural area is not always an option that a potential employee can meet.

Another aspect that hinders the functioning of disabled people in the Bieszczady poviat are the architectural barriers mentioned several times. Public utility buildings are not sufficiently adapted to the needs of the disabled - not all of them have a special elevator, the sidewalks have high curbs, residential buildings are not adapted to the needs of the disabled. People with disabilities living in the poviat must face many difficulties every day, which not only make it difficult for them to find a job, but also make daily functioning difficult. 
However, the construction law indicates that currently constructed facilities should meet certain requirements also in the context of disabled people. The regulations indicate the following factors that must be met by the building contractor:

- The construction design should include a description of accessibility for the disabled,

- It is possible to build a ramp for the disabled without the need for a building permit (Dz. U. 1994 nr 89 poz. 414).

In order to clarify these requirements, a regulation of the Minister of Infrastructure was also issued, which in an even more detailed way defines the conditions that have to be met by buildings in order to adapt them to the needs of the disabled, including the following elements:

- The entrances to the building should have hardened access roads with a minimum width of $1.5 \mathrm{~m}$, and at least one of the entrances should allow disabled people to access the entire building or its part

- Development of the building plot should take into account parking spaces for the disabled, which must be properly marked and comply with the width and length indicated in the ordinance,

- Places for collecting solid waste should be accessible to the disabled,

- At least one sanitary post must be adapted to the needs of the disabled by providing a maneuvering space and doors without thresholds, as well as handles facilitating the use of sanitary facilities,

- The location of the door and its shape should be easy to use also for the disabled,

- In buildings without levers, ramps or other technical devices to facilitate access for the disabled should be installed. (Dz. U. 2019, poz, 1065)

In general, it can be said that Polish legislation is trying to seriously approach the issue of employment of disabled people. For this purpose newer and newer legal acts to guarantee the observance of these seemingly most basic rights of every human being, not only the disabled, to a dignified life are being published. However, the reality often shows that meeting all the requirements to ensure that people with disabilities find employment in line with their preferences and qualifications is sometimes an impossible challenge.

\section{CONCLUSIONS}

Employment of a disabled person is connected with the fulfillment of certain requirements, in particular on the part of an employer. A disabled person is not automatically excluded from professional life or participation in the life of the local community. Despite certain outlays, it can continue to operate and function like any other person, and thus may turn out to be an effective employee. Due to the privileges/rights of the disabled person, other employees may get impression that they are treated unfairly by the employer, and that the disabled person is treated in a special way only in terms of their illness. Those who actually use their disability to gain their own benefit or put themselves in a more privileged position are a disadvantage. Such behavior affects the perception of disabled people through the prism of the general public - this thesis is confirmed, for example, by the events related to a disabled woman from Szczecin blocking city buses (Uwaga! Po Uwadze, materiał telewizji TVN z dnia 15.10.2018 roku) - comments related to this matter meant that a significant part of people, despite the knowledge that the behavior of this particular individual could not be equated with all other disabled people, changed their opinion about the whole group 
- in the vast majority of cases they were negative, which discouraged from taking any aid measures for any disabled person. Such situations also mean that the potential employer will not necessarily want to hire an employee with a disability - they may be afraid of the difficult behavior presented by the disabled, as well as the reception of such employment by the rest of the employees. An additional factor that hinders making such a decision is the broadly understood allegation of discrimination. The current realities mean that virtually any situation can be perceived as behavior aimed at discriminating against an employee. Court proceedings that are pending in such situations have a negative impact on the entire enterprise, even if the entire case is ended by dismissing the allegation.

\section{REFERENCES}

https://www.rp.pl/Niepelnosprawni/303309932-Koronawirus-doplaty-dla-pracownikowniepelnosprawnych.html

Mitra, S., 2006. The capability approach and disability, Journal of Disability Policy Studies, 16(4), 236-247. DOI: 10.1177/10442073060160040501

Jaglarz, E., 2017. Praca i jej znaczenie dla osób z niepełnosprawnością. Prawny $i$ społeczny wymiar funkcjonowania zawodowego osób z niepełnosprawnością, Studia Socialia Cracoviensia 9, 2(17), 181-196. DOI: 10.15633/ssc.2463

UN Convention on the Rights of Persons with Disabilities.

de Guimarães, B.M., 2015. Ergonomics and workplace adaptation to people with disabilities, Sounding Board, Work 50, 607-609. DOI: 10.3233/WOR-131814

Rozporządzenie Ministra Infrastruktury z dnia 12 kwietnia 2002 roku w sprawie warunków technicznych, jakim powinny odpowiadać budynki i ich usytuowanie, Dz. U. 2019, poz, 1065

Saja, P., Woźny, A., Pacana, A., Dobosz, M., 2017. Additional Components of Risk Assessment and Their Impact on the Probability Parameter, Production Engineering Archives, 14, 11-14. DOI: 10.30657/pea.2017.14.03

Strategia rozwiązywania problemów społecznych $w$ powiecie bieszczadzkim na lata $2020-2026$.

Ustawa z dnia 27 sierpnia 1997 roku o rehabilitacji zawodowej i społecznej oraz zatrudnianiu osób niepełnosprawnych, Dz. U. 1997 nr 123 poz. 776.

Ustawa z dnia 7 lipca 1994 roku Prawo budowlane, Dz. U. 1994 nr 89 poz. 414.

Uwaga! Po Uwadze, materiał telewizji TVN z dnia 15.10.2018 roku

Your social security rights in Poland, European Comission, European Union 2020.

Żołnierczyk-Zreda, D., Pawłowska-Cyprysiak, K., Bugajska, J., 2016. Optymalizacja psychospołecznych warunków w miejscu pracy w aspekcie potrzeb pracowników wynikających z różnego rodzaju niepełnosprawności, Niepełnosprawność zagadnienia, problemy, rozwiązania, I, (18). 